\title{
Assisted dying in the Aotearoa New Zealand media: a critical discourse analysis
}

\section{Amanda Booth \& Denise Blake}

To cite this article: Amanda Booth \& Denise Blake (2020): Assisted dying in the Aotearoa New Zealand media: a critical discourse analysis, Mortality, DOI: $10.1080 / 13576275.2020 .1823355$

To link to this article: https://doi.org/10.1080/13576275.2020.1823355

曲 Published online: 18 Sep 2020.

Submit your article to this journal $\pi$

Џ Article views: 89

Q View related articles $\llbracket$

View Crossmark data \lceil 


\title{
Assisted dying in the Aotearoa New Zealand media: a critical discourse analysis
}

\author{
Amanda Booth (iD) and Denise Blake \\ School of Psychology, Massey University, Wellington, Aotearoa New Zealand
}

\begin{abstract}
Death by assisted dying has long received media attention and remains a current socio-political health topic today. For many, understanding assisted dying is derived from media representations that position health, illness and dying in particular ways. These various stories shift and shape how we understand ourselves. With a Foucauldian lens, we explore what the media made possible for people to think, feel and do in relation to this phenomenon. From media articles collated in early 2018 we identify representations of a particularly individualised "autonomy" which intersects with assisted dying as a 'right' and necessary 'choice' to control when, where and how to die. Those with mental illness were excluded from this discourse for lacking a 'rational' sensibility. From the autonomous right to choose discourse, two subject positions arose; my choice and mine alone and the defender of rights. A counter-discourse positioning assisted dying as perilous for society and the subject position of concerned protector emerged in resistance to the autonomous right to choose. A particularly Western and privileged subject was representative of those in favour of legitimating the practice. Non-Western understandings were absent, religious and spiritual considerations marginalised, the disabled body let die, and the older adult voice silent.
\end{abstract}

\section{KEYWORDS}

Assisted dying; euthanasia; psychology; media; discourse

\section{Introduction}

While few people have direct experience of death and dying, media contextualise much of what we know about health, illness and dying. Media stories about dying are said to expose 'the most fundamental anxiety that we all face as embodied, finite beings' (Seale, 2003, p. 518). Therefore, how we come to understand assisted dying, makes mediated sources particularly influential in shaping perceptions (Somerville, 2001). As such, this research explores how media representations construct what we think, feel and practice in relation to assisted dying. Adopting a critical psychological perspective, we depart from the mainstream psychological approach that encompasses notions of positivism, objectivity and essentialism, to produce knowledge that situates assisted dying and its practices as socially constructed. We explore the historical, socio-political and culturally specific nuances of assisted dying, paying attention to the effects of language and power. This approach opens 
up an understanding of the wider contextual and structural forces that serve to shape thoughts, feelings and actions with regard to end-of-life decisions in contemporary times. Accordingly, the following work draws on both published studies and media stories related to proposed legislation, known as the End of Life Choice Bill (EOLC Bill), ${ }^{1}$ that was working its way through parliamentary debates and public consultations in Aotearoa New Zealand during 2017 to 2019.

\section{A comment on terminology}

We recognise that any term we use is contestable and open for redefinition (Tuffin, 2005). The term 'assisted dying' is associated with the Aotearoa New Zealand legislation and has specific meaning. Assisted dying in this article refers to the intentional and voluntary ending of life of a competent person either by their own hand, medical person, or nominated other. This term is used interchangeably with the term euthanasia.

While global literature is reflected in this article, our introduction necessarily emphasises Aotearoa New Zealand research to situate this story. Extant research exploring the portrayal of assisted dying specifically within the Aotearoa New Zealand news and social media is limited. However, Lewis (2005) noted two competing discourses in the Aotearoa New Zealand news media during 2002 to 2004. The sanctity-of-life discourse which drew on the notion that 'God' controls the time of death, and the right-to-die discourse that challenged the law with appeals to personal liberty. Winnington (2016) analysed Aotearoa New Zealand and British social media accounts from 2010 to 2015 concluding that patient choice is an idealised construct that is unachievable in actuality. The 'good death' was a medicalised death, and in collaboration with the law, media represented medical power as necessary to the dying process. Moreover, any self-determined 'individual' who supported the right-to-die was positioned as Other to the norm, and labelled deviant. Revell-Dennett (2018) identified that the Aotearoa New Zealand news media offered a subtle moral discourse that shifted over time. Euthanasia as 'murder' became 'mercy killing', and recent pro-euthanasia advocates were portrayed as heroes and martyrs in their fight against the legal system. Media were accused of producing limited discourse compared with experts, thus denying the complexity of the issue. Echoing Revell-Dennett, Jaye et al. (2019) argued Aotearoa New Zealand media represent the assisted dying debate in simplistic binary terms, whereas, social media accounts presented a broad range of positions, entrenched sociocultural values and challenged the role of the State in matters of dying (Jaye et al., 2019). Across all four studies traditional voices of authority were contested, and we see examples of power circulating between the institutions of the Church, Medicine and the Law.

Broadly speaking, present-day understandings of assisted dying in Aotearoa New Zealand are positioned in the media as two sides of a coin, those in favour of legalisation, and those against. While binary frames simplify complexity and appeal to journalistic practices about timeliness and conflict; media is not a neutral reflection of 'reality', but a site of power that marginalises alternative views through the representation of hegemonic perspectives held by socially privileged groups (Ott \& Mack, 2010). Importantly, through 'reflecting public opinion' media enables and constrains the conditions that make social policy such as the End of Life Choice Act 2019 possible (Hodgetts \& Chamberlain, 2006). 


\section{Methodological considerations}

This work draws from Foucauldian ideas about social power operating in discursive contexts. As the terms discourse, power, and the self are understood in multiple ways, we state how we take these up. We view discourses as patterns of text that form objects at historically contingent times and places, like the media producing particular forms of euthanasia. Thus, discourses about euthanasia can be both an instrument and an effect of power; they transmit, produce, undermine and expose power (Foucault, 1978, 1980). Imbued with power, discourses offer us subject positions that have implications for what we can think, say, feel and do (Arribas-Ayllon \& Walkerdine, 2017). We understand the self as a body inscribed by discourse. This understanding does not deny personal agency, as counter-discourses and new subject positions eventually emerge (Yates \& Hiles, 2010) and a person can assume or resist subject positions (Burr, 2015). We also recognise that there is a world beyond the text, and give ontological status to aspects of the material world, such as pain and death (Parker, 1998).

The influence of neoliberalism, disability and ageing in how euthanasia is constructed is also considered in this work. We explore how neoliberal practices intersected with euthanasia discourse in Aotearoa New Zealand media and apply Foucault's perspective of neoliberalism as a set of values, ideas, policies and language that emerged to unsettle the State's authority over various aspects of people's lives (Flew, 2014). Disability and ageing were chosen as analytical lenses because they are often conflated with the practice of euthanasia to devalue the lives of disabled people ${ }^{2}$ and older adults (Haller \& Ralph, 2001; McInerney, 2007; Schwartz \& Lutfiyya, 2009). Following the thinking of Luna (2009) that vulnerability is inessential, layered and dynamic, we contend any person with socialised expectations to be healthy or facing a financial challenge can be positioned as vulnerable. We were, however, interested in how the disabled or ageing body was perceived, negotiated, reinforced and/or challenged.

\section{Methods}

Media data were collected by the first author over a three-month period in 2018, when two critical discourse events occurred. Critical discourse events provide greater opportunities to trouble taken-for-granted discursive positions (Carvalho, 2008). The first event was the trial and eventual acquittal of Susan Austen for aiding and abetting Annmarie Treadwell to commit suicide Susan Austen trial verdict: not guilty of aiding suicide, 2018). The second event was the proposal led by David Seymour of the $\mathrm{ACT}^{3} \mathrm{New}$ Zealand political party to legalise assisted dying; the End of Life Choice Bill (EOLC Bill). From a total corpus of 66,150 words, text was analysed from 45 articles collated from four newspapers: The New Zealand Herald; Stuff; The Dominion Post; and The Press. A further 500 responses to Stuff articles open to public comment were also analysed. As a research team constrained by English language, we understand that a more diverse media selection would likely expose alternative discourses. We also accept there are other ways of asking questions, interpreting findings and representing texts (Gergen, 2011). As such, this work has been influenced by our conceptual and theoretical approaches, the data sources and our socio-political locations as researchers. 
Foucauldian Discourse Analysis as presented by Willig (2008) was used to interpret the data. We searched for oppressed, marginalised and subordinated meanings along with any normalising tendencies. Instances of disciplinary power where bodies accepted control and instruction and policed their health and illness were noted. Biopower, conceptualised as the State's requirement to control its population through various apparatus such as health policy (Foucault, 1975-76 (2003)) was pursued by looking for statements that referred to the manipulation of mortality rates. Text was reviewed for suggestions of governmentality, or the 'conduct of conduct'; the governing of self and others (Foucault, 1975). Inferences of transformative practices that sought quality of life and happiness, such as healthism (see Crawford, 1980, Crawford, 2006), and practices of responsibilisation and normalisation were analysed. Additionally, subject positions as produced by the media and taken up by readers were explored. This included looking at what could be enacted from within these positions, along with hypothetical contemplation of thoughts, feelings and experiences. We acknowledge subject position formation takes place across multiple sites, not only from engaging with media (Türken et al., 2015). However, in this article, media is the site of analysis.

Ethics approval was granted by the Massey University Ethics Committee, Notification Number: 4000019549. We acknowledged the tension between public/private spaces so further safeguards were adopted with the published material as it related to sensitive health information. The public comments, herein called reader responses use fictitious names for ease of reading.

\section{The autonomous right to choose discourse}

The Aotearoa New Zealand media had three separate but interrelated patterns of text that functioned to produce the prevailing autonomous right to choose discourse: 'individual autonomy', 'rights' and 'choice'. What follows is a selection of quotes that represent this discourse, the construction of a counter-discourse and extracts from the subject position analysis.

Media primarily constructed death by assisted dying as an individual exercising of autonomy. For instance, the campaign slogan for the EOLC Bill '\#MyLifeMyChoice' signifies individual ownership of life and that such ownership equates to a choice. This notion was supported by other texts, such as the following quote from Carroll, a spokesperson for the \#MyLifeMyChoice campaign. Carroll also reinforces the importance of autonomy:

'Carroll said she alone should choose when her life would end' (Nichol, 2018).

That 'she alone' should decide when to die can be read in multiple ways. It could mean that consultation with friends and family about matters related to death is unnecessary. It could also be assumed that dying should not be influenced by ideology, religion, medicine, or the law. Positioning assisted dying as a matter of individual autonomy means decisions appear free from coercion. The exercising of autonomy was similarly represented in the British media where people who enacted euthanasia were depicted as independent and self-determined (Birenbaum-Carmeli et al., 2006). In addition to an individualised autonomy, assisted dying intersected with medical discourse to exclude the mentally ill. This exclusion is apparent in Seymour's comments below: 
'A person with any kind of serious mental illness, by definition, has a distorted view of what ending their life means. If your argument is I'm depressed and I want assisted dying, the rules actually exclude you' (Manch \& Nyika, 2018).

As represented here, people with 'serious mental illness' are positioned as having a 'distorted view' and as such cannot logically weigh up end-of-life decisions. Notions of a rational consciousness are commonly equated with autonomy (Vulcănescu, 2018). The classification 'serious mental illness' (which we assume refers to 'disorders' such as bipolar disorder, schizophrenia, major depression and dementia) is taken-for-granted as innate, rather than constructed by medical discourse. There was no suggestion that a person with a serious mental illness could exercise autonomy and self-rule, even undergoing treatment. The exclusion of an irrational/insane self, from the autonomous right to choose discourse worked to distance the practice of suicide from assisted dying.

The autonomous right to choose discourse promoted assisted dying as a progressive 'human right'. Drawing on rights discourse, assisted dying was claimed as both a moral and legal right by the following Members of Parliament (MP's):

'Like the 9/11 jumpers, people who choose to exercise their autonomy in expressing their rights as they face foreseeable death should not be seen as doing something wrong or sinful' (Wall, 2018).

'... Seymour, described end of life choice as New Zealand's last great human rights hurdle. "The one area where we don't have full autonomy over our bodies and our lives is when we die" (Walters, 2018a).

The first quote represents how Louisa Wall (MP) constructed assisted dying as morally permissible by distancing it from a 'sinful' death. A death that is sinful calls upon Church rhetoric that denounces self-destruction as a form of self-murder (Ryan et al., 2011). This also serves to distance assisted dying from suicide. Assisted dying was not only represented as the 'last great human rights hurdle', it was assumed to be an inherited right and freedom within a 'Western anglosphere nation' by Seymour (MP) (Walters, 2018a). Anglosphere culture reveres individualism and 'excludes people who define themselves primarily as members of collective entities' (Bennett, 2002, p. 114). Similar studies also found the construction of euthanasia as a right. For instance, in Britain choosing euthanasia was considered a birth right (Hausmann, 2004), while in North America and Canada, the media privileged stories about individual rights and freedoms (Clarke, 2005).

Choice, as a strong theme within the autonomous right to choose discourse, intersected with notions of individual control. Choices related to preserving dignity, self-respect and reinforced rights on how, when, and where to leave the world. The next extract is taken from Louisa Wall's (MP) opinion piece:

'People who have a terminal illness and can no longer be helped and who want to choose how, when and where they die should be supported to end their lives in dignity and selfrespect' (Wall, 2018).

To not choose death by assisted dying, produced death without assisted dying as undignified. This depiction has the potential to evoke feelings of empathy and kindness towards those facing loss of 'self-respect'. It also potentially raises fear of losing control of the dying process. Unlike the social media accounts noted by Winnington (2016), absent from this discourse was any understanding that patient choice was an illusion. 
Choice also intersected with privilege. Pro-euthanasia advocates were portrayed as socially and materially resourced and 'elite'. References such as marriage to a diplomat, living abroad, and university education ('Woman Accused'”, 2018; 'Diary reveals' , 2018) were embedded within stories about the trial of Susan Austen, accused and acquitted for helping Annmarie Treadwell die. These stories of privilege are similarly reflected in the following quotes:

'In Oregon, assisted dying is an overwhelmingly middle and upper-middle class phenomenon. The people that choose euthanasia ... are the people with health insurance and access to good palliative care' (Walters, 2018b).

'Four years ago, I sat by my mother's bedside .... While she had access to all the medication and nursing care you could ever want, she wanted the right to choose her own time'(Young, 2018).

The first quote by Seymour (in Walters, 2018b) informs readers that euthanasia is a 'middle and upper-middle class phenomenon', taken here to signify a group of people with resources and social power. The second extract is from a story where a mother has access to all she needs, except her 'right to choose' assisted dying. In North American and Canadian magazines euthanasia was similarly fashioned as a privileged death which ignored the experiences of poor and racialised groups who had little choice over the time or place of death (Clarke, 2005). In the final extract below, we return to the story of Carroll, one of the advocates of the \#MyLifeMyChoice campaign:

'Dying after becoming so sick you could not speak or recognise loved ones was not dying with dignity, Carroll said ... if she could choose, she'd have a party to celebrate her death, surrounded by her partner of 40 years, their children and grandchildren' (Nichol, 2018).

In the Aotearoa New Zealand media choosing assisted dying before cognitive decline appeared a principal concern, unlike Britain and Australia, where euthanasia was produced as a strategy to avoid corporeal failure (Birenbaum-Carmeli et al., 2006; Mclnerney, 2007). A life where you cannot 'speak or recognise loved ones' was rendered undignified, with assisted dying presented as a necessary choice. By suggesting that death could be a 'party', positive feelings of death are engendered. The extract above intersects with a revivalist discourse, the modern 'good death' in which death occurs as an 'aware' death in the presence of loved ones before the 'dissolution of the social bond' (Seale, 1998, p. 183). To choose euthanasia opens up the possibility of a modern good death.

\section{Subject positions: my choice and mine alone, and the defender of rights}

Discourses provide readers with subject positions about how to think, say, feel and respond (Arribas-Ayllon \& Walkerdine, 2017) and are pivotal to decisions regarding assisted dying. In the context of the autonomous right to choose discourse, the self is offered two subject positions to embody; my choice and mine alone, and the defender of rights. To claim my choice and mine alone readers drew upon individualistic constructions of euthanasia. Strong emotions were expressed within this subject position, such as braveness, frustration and anger: 
'How about just letting me make up my own mind on my end of life choices. It's nobody else's business. I say butt out of my life and its ending ... I want to be able to make this decision while I still have my faculties and can make a rational call ... I don't need politicians and do gooders influencing my choice and mine alone' (Caelan).

It was emphasised that decisions related to end-of-life choices were the prerogative of the individual. Caelan's account conveys this sentiment as they express indignation and a sense of injustice that this choice was not theirs to make.

Akin to the rational aspect of the autonomous right to choose, choices for Caelan needed to be actioned while a person still had their 'faculties'.

Taking up the subject position of my choice and mine alone required a rejection of the Church in matters of death. Numerous reader responses suggested that those who held religious views were insane and irrational; to be religious was to be positioned as Other. Those who identified with religious or faith-based arguments were disallowed entry:

'If you allow religion into the debate, common sense is immediately excluded.

Religion or reality; you can't have both' (Max).

'Perfectly stated. Couldn't put it better myself. I say my life, my choice. Certainly, no business of the religious nutters spewing forth their moronic garbage' (Dana).

According to Max, religion and reality are mutually exclusive, while Dana pathologized religion. Each excerpt demonstrates a strong need to maintain personal agency and choice. Unlike Lewis's (2005) research, a sanctity-of-life discourse was not prominent in our media sample, reducing the need for the those holding the subject position of my choice and mine alone to engage with alternative belief systems.

Medical control of the body was also challenged in the my choice and mine alone subject position. The authority of Medicine to restrict choice in pain-relieving drugs was disputed, particularly morphine, a well-recognised opioid analgesic used in cancer care. Challenged on the basis it changed 'a person's personality', medical cannabis was considered superior by some. Medicine's ability to provide a peaceful death was also contested:

'Morphine is a shocking drug, changes a person's personality ... I don't know why the medical profession push that as there are alternative medicines ... even medical cannabis would be a far better alternative' (West).

'Maybe the focus should be on allowing people to do what they want with their bodies.... Whether people then choose to use it (pentobarbital), and die peacefully should be a matter of personal freedom' (Frances).

In holding the subject position of my choice and mine alone, medical endorsement of pentobarbital was important, along with individual control over the timing of death. Drawing from neoliberal values depicted in the autonomous right to choose discourse, choosing when to die was a matter of 'personal freedom'.

The second subject position; the defender of rights promoted the right to choose death by euthanasia. The rights of the disabled ${ }^{4}$ person appeared to be co-opted by the nondisabled who freely commented on their situation:

'In my experience, people with a disability have been advocating for the same rights in every part of life for years, why should that be different for death?' (Easton). 
'It is discriminating against disabled people to not be allowed the choice .... There will be a small (very small) number of them who genuinely want to die for very sound and sane reasons' (Tanner).

As seen in the exchange between Easton and Tanner, the defender of rights subject position evoked a sense of morality and justice by looking out for, and championing, the rights of others less able. It appeared to produce experiences of unity and solidarity. However, it also pathologises the disabled person as the Other to the healthy non-disabled norm, and permits practices of surveillance and risk management (Saltes, 2013). It can be assumed that the person who adopts this position draws on democratic ideals and concern for the community; however, conversely they could be acting in self-interest (Shildrick, 2015) as defending the rights of disabled people may also be viewed as an insurance policy against future disability, with assisted dying an escape route. Overall, this subject position takes on a form of morality similar to Crawford's (1980) healthism discourse, where we are required to be health conscious and perform 'health' in self-disciplined ways.

While the disabled body was allowed to let die in defence of 'human rights', the aged body was suitable for euthanasia. In occupying the subject position of the defender of rights, it was morally and ethically permissible for an elderly body to die by assisted dying. The comments below follow this line of thought:

'We have an ageing society in an already over populated world, why oppose those with valid reasons to end their own life and die on their terms' (Ray).

'Could be tweaked in the future to include whittling down the baby-boomers. Seemingly, the young regard them as Public Enemy \#1' (Blaine).

In Ray's comment, the so-called 'ageing society' problem can be addressed by allowing older adults the right to die. Intersecting with discourses of the older person as an economic burden, this commentary positioned older adults as the problematic Other for using resources in an 'over populated' world. The autonomous right to choose discourse conflated age with euthanasia; the ageing body considered expendable provided the individual could take on the notion of rationality and produce 'valid reasons to end their own life'. Acknowledging that margins for resistance are limited, some challenge was made to the autonomous right to choose discourse with nine of the 45 articles analysed representing euthanasia as a perilous choice.

\section{Counter discourse: perilous}

Rejecting the discourse of autonomous right to choose, euthanasia was also portrayed as a dangerous choice for society, in particular for disabled and elderly people. As outlined earlier, the autonomous right to choose discourse focussed on the autonomous individual who made decisions without the influence of other people, ideologies or institutions. The perilous discourse, on the other hand, centred on protecting those assumed to be vulnerable:

\footnotetext{
"'The biggest danger is the subtle coercion," says Kleinsman, that somehow, elderly people do not have a place in our society anymore; that people with disabilities who are dependent don't have a place in our society' (Walters, 2018b).
} 
'MP Maggie Barry ..., sees liberalisation as an "inevitable outcome" of the legislative process a conveyor belt of human misery on which we will eventually load the burdensome elderly, disabled and, yes, children' (Walters, 2018b).

Disabled and older people are considered a burden to society and as such, human rights advocates seek to protect their wellbeing as both quotes demonstrate. Euthanasia opponents argue for the protection of vulnerable people from coercive practices, claiming that legalising euthanasia risks an extension of the eligibility criteria overtime (Keown, 1995). These arguments are embedded in the perilous discourse with bodies outside of the norm acted on by 'subtle' negative forces and neoliberal ideology. Portraying assisted dying as perilous may evoke feelings of fear of future disability, and a moral sense of duty for people to protect others. It may also conjure up fear of becoming a burden. Winnington (2016) likewise noted Aotearoa New Zealand and UK media portrayed euthanasia as dangerous for people who feel obligated to request euthanasia for fear of burdening their families or the State.

In addition to considerations about exercising individual autonomy and challenge to the doctor/patient relationship, the perilous discourse unsettled the idea that euthanasia results from rational decision-making. The following extract refers to comments from Kylee Black. Once able-bodied Kylee is named as a fierce opponent of assisted dying as she holds onto life:

'Black does not want to die. And she does not want doctors suggesting death as an option to her, especially on her darkest days' (Akoorie, 2018).

Whereas other research highlighted concerns that legalising euthanasia may lead to decisions being taken on a person's behalf (Winnington, 2016), in the perilous discourse, it was 'doctors suggesting death' that was rejected. The role of Medicine participating in talk about assisted dying as a possible end-of-life choice was challenged. Additionally, doubt was cast on the idea that decisions about death could be rational by reference to 'dark' transient moods. The construction of euthanasia as perilous also enabled disability advocates to underscore other issues of human rights and inequities (e.g., inadequate housing, lack of innovative and assistive technologies) facing the disabled community in Aotearoa New Zealand.

\section{Subject position: concerned protector}

The positioning of euthanasia as perilous, made possible the subject position of concerned protector. Those who assumed this position spoke of concern for vulnerable people, most notably, the disabled and elderly. The following exchange between Jackie, Sonny and Byron represents this stance:

'Terminal illness and major disability can be viewed as much the same thing by society' Jackie.

'When I think of euthanasia, disabled people don't even come to mind' Sonny.

'They don't for most people. Nor do other vulnerable people such as the elderly ... My opposition to euthanasia is not religious or moral but concern for these kind of people' Byron.

Jackie becomes a concerned protector when she argues against conflating a 'major disability' with a terminal illness. As found in the Schwartz and Lutfiyya (2009) study, when 
Canadian media confounded terminal illness and disability it risks encouraging disabled people who were not near the end-of-life to enact euthanasia. Rather than assuming the defender of rights subject position (claiming euthanasia as a right for disabled people), Sonny states disabled people 'don't even come to mind' as the EOLC Bill is about 'you and me', which we assume to mean the non-disabled normative person. Byron further extends the safeguard of vulnerable people to include the elderly. As with the defender of rights position, the concerned protector did not claim religious moral authority. Putting others before the individual self was paramount thereby contesting neoliberal ideology. In this way, the notion of autonomous choice was also challenged as noted below:

'The biggest issue with 'freedom of choice' is that it puts pressure on those who feel like a burden' Byron

'For every Lecretia Seales, there are 10 people, ugly, poor, intellectually disabled, already considered worthless by a market economy, trying to live. Euthanasia exerts a powerful pressure on them that robs them of their choice' Tobias.

Byron and Tobias taking up the concerned protector dispute euthanasia as a function of choice. For Tobias, society is depicted as unjust when it values those with social and material means, such as Lecretia Seales ${ }^{5}$ portrayed in the media as an attractive, apparently wealthy lawyer (Revell-Dennett, 2018) over people considered 'burdensome' and 'worthless'. In the final quote we turn to Matt who highlights the transitory nature of emotions, thus challenging the taken-for-grantedness that assisted dying is the choice of the rational mind:

'These feelings of unbearable suffering can pass as stuff happens - people are so unpredictable. Allowing them to end their life when they have hit a low is not reasonable' Matt.

Emotions have a long history of being marginalised as a valid expression of an authentic being. As the constitutive other of 'reason' and linked to the rational subject, emotions are positioned as problematic for the vulnerable in the making of significant life choices. While this is an important consideration, the position of concerned protector is primarily about protecting those who are considered vulnerable and with little social power.

\section{Discussion}

The construction of euthanasia in the Aotearoa New Zealand media is defined by patterns of discourse that emerge from the text alongside what is oppressed or marginalised, and what and who is rendered silent or absent altogether. Here we offer a reading, attending to neoliberalism, disability and ageing as conceptual lenses applied to the analysis, alongside other potential implications of the media construction.

\section{Disability and ageing}

As previously mentioned, the autonomous right to choose discourse worked to exclude those with disability, including mental illness which can be labelled as a disability, echoing mainstream research where euthanasia is portrayed as the product of the autonomous, rational, independent person (Den Hartogh, 2016). Euthanising people who suffer from mental illness does not fit the traditional notion of autonomy, as rational control over 
death is questionable. Furthermore, those experiencing mental illness are commonly viewed as incapable of making a competent or coherent choice (Hewitt, 2013). These media assertions highlight the cultural and historical specificity of Aotearoa New Zealand, for while 'serious mental illnesses' are exclusionary criteria in many jurisdictions (Vulcănescu, 2018), in Canada and the Benelux countries, people who have psychiatric disorders are allowed to request euthanasia (Evenblij et al., 2019). While all of these considerations are important, critically the autonomous right to choose discourse presents euthanasia as a binary choice: available for the sane and rational body, but not the insane and irrational mind. In doing so it privileges the preservation of the mind as 'healthy' or otherwise over the body.

In the period analysed, discussion around what 'autonomy' means to a disabled person was absent, with loss of autonomy produced as something to fear. The concept of supported autonomy, a notion that acknowledges relationships in the practice of exercising self-determining actions for disabled people, was overlooked (Bouwmeester et al., 2010). This potentially marks those for whom dependency on others is an everyday occurrence as Other to the 'healthy norm'. Absent from the autonomous right to choose discourse and the perilous discourse was the notion that living in an impaired mind or body was something that could be celebrated. Alison Kafer refers to this portrayal of disability as the 'ableist failure of imagination' (Kafer, as cited in Fritsch, 2015, p. 44). Cohering with research from North America and Britain that failed to present positively the experience of life with a disability, this writes a celebrated disabled life out of existence (Haller \& Ralph, 2001; Schwartz \& Lutfiyya, 2009).

These understandings also matter to the experiences of older people, who have often been produced in the media as the problematic 'Other' through representations of 'frailty' and 'dependence', coupled with a concern about rising public health costs (Hurley et al., 2017). Such discourses produce the aged body as an economic burden. Although alternative discourses such as healthy ageing appear less injurious, they give rise to a new norm that has ageing occurring without cognitive or functional decline (O'Rourke \& Ceci, 2013). Discourses of burden and healthy ageing potentially act upon the older person to invoke euthanasia as the solution to the burdensome old person's duty to die (Balch, 2017). In the media, dividing practices of young/old aligned with portrayals of ageing where colloquial terms such as 'baby boomers' were used to position the older adult as an economic drain and undesirable in an 'over populated world'. Furthermore, loss of mental health for older people was a prominent justification for euthanasia.

What was particularly noticeable was the lack of direct comment about what it means to be an older adult in Aotearoa New Zealand, and the absence of any older person's advocacy group in discussing the assisted dying debate. This could be read that older adults avoided situations that might expose them as Other. Another possible reading is that they were not invited by the media to discuss their views. In media constructions of euthanasia what it means to an older person was taken for granted. The media discourse failed to embrace the gerontological imagination of an older person's life as a life worth living.

The labelling of disabled and aged people as vulnerable in the perilous discourse fixes vulnerability to a person because of certain 'essential' characteristics, and in doing so, people are placed in a hierarchy against those who are young, healthy, strong, and nondisabled. Although likely not intentional, by demarcating such groups as vulnerable to 
coercion and undue influence, they reaffirm negative stereotypes (Burchardt, 2017) and reproduce conditions of oppression. Many disabled or older people live in supportive family/whānau ${ }^{6}$ structures, where interdependence or dependence are socially acceptable practices.

\section{Exercising governmentality: church, medicine and the state}

During the period analysed, autonomy, rights and choice collectively reduced the power of the Church and the institution of Medicine. The authority of the Church was challenged in determining moral boundaries as they relate to a self-determined death. Globally, the holding of religious views influences opposition to euthanasia (Emanuel et al., 2016; Löfmark et al., 2008), yet opposition by the Church was barely carried through into the Aotearoa New Zealand media. This may be due to media's gatekeeping practices, or a subtle exercising of dominant liberal ideologies and the persuasion of pro-euthanasia interest groups who frame issues to meet news entertainment values. It might also speak to the taken-for-grantedness that 'choosing' when and how to die was the prerogative of the individual. Religious based arguments were afforded little space when compared to pro-euthanasia arguments, echoing other research that found the Church was marginalised in the media and relegated to the end of news articles (Birenbaum-Carmeli et al., 2006).

Opposition to medical power was more subtle. It largely came from medical personnel and readers who took up the my choice and mine alone and defender of rights subject positions. Medicine was portrayed as antiquated and antithetical with patient needs. Another challenge to Medicine's power related to the place and manner of death. While most deaths occur in private settings (Lyons \& Chamberlain, 2006), death by euthanasia was a more public affair with the dying person surrounded by loved ones at a location of their choosing. Medicine's absolute control over the dying process was thus contested. Conversely, it could also be argued that medical power was simultaneously maintained through its role in the construction of illness and disease categories that determine which bodies are allowed to die according to euthanasia legislation, and through medicine's role in provisioning the necessary medication, thus echoing Winnington's research that claimed patient choice in the dying process is an illusion (Winnington, 2016).

In the Aotearoa New Zealand media, the State was the facilitator of the neoliberal notion of 'freedom of choice', seemingly acting in the interests of democracy and the desires of its people. This representation differs from British research that portrayed the State as an outdated apparatus that failed its citizens by disrupting their dignity in dying (Birenbaum-Carmeli et al., 2006). It could be claimed that State action to legalise assisted dying increases exposure to death for some people. To 'let die' by euthanasia appears to manage the paradox requiring behaviour to be both regulated and manipulated by the State, while at the same time asserting the sovereignty of the 'autonomous individual' (Foucault, 1975).

\section{Privileging the 'Western' subject}

We want to comment on the way in which autonomy, rights and choice depicted a particularly Western subject. Non-Western values that might matter to euthanasia 
discourse such as interdependence, reciprocity, and kinship were underrepresented (Ranzijn, 2010). Engaging neoliberal values of individualism and rationality while ignoring family relations shares similarities with other critical research (for example, see Birenbaum-Carmeli et al., 2006; and Clarke, 2005). Importantly, perspectives of health that incorporated familial, social and spiritual aspects were largely absent. These nonWestern values resemble values associated with a Māori ${ }^{7}$ worldview, highlighting the asymmetry of mainstream media. In consideration of the EOLC Bill, this was important as the Bill provides for a person to request assisted dying without the knowledge of their extended family/whānau (Turia, 2019).

Māori voices were widely underrepresented across the articles examined with only one Māori interviewed, Dr Lance O'Sullivan (Nga Toa Whakaihuwaka, Supreme Māori of the Year 2013 and New Zealander of the Year 2014), who fronted the assisted dying campaign \#MyLifeMyChoice. Māori values such as whanaungatanga, ${ }^{8}$ wairuatanga, mauri, and tikanga practices related to tangihanga that might matter to euthanasia were not examined. This lack of representation is unsurprising. In Aotearoa New Zealand, a colonised nation, stories from Māori generally are missing in the mass media and there is a lack of Māori led mass media publications in contemporary times (Rankine et al., 2014). With such absence, it is reasonable to assume that mainstream media has the potential to influence Māori and non-Māori minds alike.

The omission of euthanasia in the context of 'being Mãori' could be read many ways. It may be due to the colonising effects of mass media to reinforce dominant norms (Rankine et al., 2014). It may be that euthanasia is claimed to be both culturally foreign to Māori and enacted historically (Malpas et al., 2017) troubling media's tendency to report euthanasia news in a dichotomous way. Notably, the absence of any consideration of Māori culture and ideals is striking. With the proposed assisted dying referendum set for the 2020 Aotearoa New Zealand election, it would be important to do culturally engaged research in this space.

\section{Conclusion}

Discourses capture historically contingent moments. Following two years of public discussion and parliamentary debate in regard to the referendum, new discourses of assisted dying are emerging and we are witnessing media represent both sides of the debate. However, at the time of analysis, the portrayal of euthanasia in the Aotearoa New Zealand media transmitted neoliberal ideals of individualism, choice, and rationality and produced euthanasia as the right of the Western-privileged subject. The autonomous right to choose discourse undermined the power of Church and exposed the struggles between Medicine and individual autonomy in matters related to the dying process. Although marginal, a counter-discourse perilous was offered. Rather than reflecting on the dangerous side of normative standards and false dichotomies, the nondisabled/disabled and young/old categories were reinforced. The media's selective portrayal presented a particular way of understanding assisted dying that risks harm to non-dominant cultures and groups that engage with mainstream media. Critically, in focussing so strongly on the rights of the individual to choose a death of their liking, other important issues such as culturally appropriate healthcare, equal quality and material resources are hidden. 


\section{Notes}

1. The EOLC Bill is now known as the End of Life Choice Act 2019 and is located at: http://www. legislation.govt.nz/act/public/2019/0067/latest/DLM7285905.html?src=qs

2. The term 'disabled people' refers to people with impairments which can be mental, physical, or sensory, and who experience disabling practices (Oliver, 2013).

3. ACT stands for Association of Consumers and Taxpayers, a lobby group from which the political party originated.

4. The EOLC Bill allowed for disabled, but non-terminal people to request assisted dying. The EOLC Act states a person must suffer from a terminal illness.

5. Terminally ill with cancer, Seales unsuccessfully sought the right to end her life with the support of a doctor, on the basis that the Crimes Act was inconsistent with the Bill of Rights.

6. Whānau (extended family).

7. Māori are the indigenous people of Aotearoa New Zealand.

8. Whanaungatanga translates as (kinship), wairuatanga (spiritual practices), mauri (life force) tikanga (cultural practices) and tangihanga (funeral practices).

\section{Disclosure statement}

No potential conflict of interest was reported by the author(s).

\section{Notes on contributors}

Amanda Booth has a degree in sociology and psychology from the University of Canterbury and a master's degree in science with a health psychology endorsement from Massey University. She currently works in the Not-for-Profit sector as a project coordinator. Her research interests include ecofeminist understandings of climate change, spirituality, resilience, health promotion and intergenerational wellbeing.

Denise Blake is a Senior Lecturer for the Joint Centre for Disaster Research and the School of Psychology. She teaches critical health psychology and emergency management courses. Her research concerns issues of social justice, including identity, welfare, health promotion and disaster management. She is currently involved in projects that explore opioid substitution treatment, sex workers rights and homelessness in disaster contexts, and Māori experiences of adoption and whāngai. Denise values using collaborative and community embedded research approaches to complex social issues.

\section{ORCID}

Amanda Booth (D) http://orcid.org/0000-0002-8903-2329

\section{References}

Akoorie, N. (2018). End of life choice bill alarmingly ambiguous for disabled people - Kylee Black. The New Zealand Herald. https://www.nzherald.co.nz

Arribas-Ayllon, M., \& Walkerdine, V. (2017). Foucauldian discourse analysis. In C. Willig \& W. Stainton Rogers (Eds.), The SAGE handbook of qualitative research in psychology (pp. 110-121). Sage Publications. Issue 2nd. https://doi.org/10.4135/9781848607927.

Balch, B. (2017). Death by lethal prescription : A right for older people - Or their duty? Journal of the American Society on Aging, 41(1), 42-47. doi:10.2307/26556264

Bennett, J. (2002). The emerging anglosphere. Orbis, 46(1), 111-126. https://doi.org/10.1016/s00304387(01)00109-0 
Birenbaum-Carmeli, D., Banerjee, A., \& Taylor, S. (2006). All in the family: Media presentations of family assisted suicide in Britain. Social Science and Medicine, 63(8), 2153-2164. https://doi.org/10. 1016/j.socscimed.2006.05.004

Bouwmeester, R., Harpe, W., \& Polhuis, D. (2010). Supported autonomy. Journal of Cognitive Rehabilitation, 28(3), 4-10. https://www.ggzvs.nl

Burchardt, M. (2017). Diversity as neoliberal governmentality: Towards a new sociological genealogy of religion. Social Compass, 64(2), 180-193. https://doi.org/10.1177/0037768617697391

Burr, V. (2015). Social Constructionism (3rd ed.). Routledge.

Carvalho, A. (2008). Media(ted) discourse and society: Rethinking the framework of critical discourse analysis. Journalism Studies, 9(2), 161-177. https://doi.org/10.1080/14616700701848162

Clarke, J. N. (2005). Death under control: The portrayal of death in mass print English language magazines in Canada. Omega-Journal of Death and Dying, 52(2), 153-167. https://doi.org/10. 2190/COE2-YTE3-PR9T-7JAV

Crawford, R. (1980). Healthism and the Medicalization of Everyday Life. International Journal of Health Services, 10(3), 365-388.

Crawford. (2006). Health as a meaningful social practice. Health, 10(4), 401-420. https://doi.org/10. 1177/1363459306067310

den Hartogh, G. (2016). Two kinds of suicide. Bioethics, 30(9), 672-680. https://doi.org/10.1111/bioe. 12287

Diary reveals woman's emotional plight. (2018, February 24). The press. https://www.stuff.co.nz/thepress/

Emanuel, E. J., Onwuteaka-Philipsen, B. D., Urwin, J. W., \& Cohen, J. (2016). Attitudes and practices of euthanasia and physician-assisted suicide in the United States, Canada, and Europe. Journal of the American Medical Association, 316(1), 79. https://doi.org/10.1001/jama.2016.8499

Evenblij, K., Pasman, H. R. W., Pronk, R., \& Onwuteaka-Philipsen, B. D. (2019). Euthanasia and physician-assisted suicide in patients suffering from psychiatric disorders: A cross-sectional study exploring the experiences of Dutch psychiatrists. BMC Psychiatry, 19(1), 1-10. https://doi. org/10.1186/s12888-019-2053-3

Flew, T. (2014). Six theories of neoliberalism. Thesis Eleven, 122(1), 49-71. https://doi.org/10.1177/ 0725513614535965

Foucault, M. (1975). Society must be defended. Lectures at the College de France 1975-76 (M. Bertani \& A. Fontana, ed.). Picador.

Foucault, M. (1978). The history of sexuality, volume one: An introduction. Pantheon Bookd.

Foucault, M. (1980). Power/Knowledge: Selected interviews and other writings 1972-1977. Harvester Press Limited.

Fritsch, K. (2015, June). Desiring disability differently: Neoliberalism, heterotopic imagination and intra-corporeal reconfigurations. Foucault Studies, 19, 43-66. https://doi.org/10.22439/fs. v0i19.4824

Gergen, M. (2011). Qualitative methods in feminist psychology. In C. W. \& W. Stainton-Rogers (Eds.), The SAGE handbook of qualitative research in psychology (pp. 280-296). Sage Publications Ltd. https://doi.org/org10.4135/9781848607927.n16

Haller, B., \& Ralph, S. (2001). Not worth keeping alive? News framing of physician-assisted suicide in the United States and Great Britain. Journalism Studies, 2(3), 407-421. https://doi.org/10.1080/ 14616700120062248

Hausmann, E. (2004). How press discourse justifies euthanasia. Mortality, 9(3), 206-222. https://doi. org/10.1080/13576270412331272798

Hewitt, J. (2013). Why are people with mental illness excluded from the rational suicide debate? International Journal of Law and Psychiatry, 36(5-6), 358-365. https://doi.org/10.1016/j.ijlp.2013. 06.006

Hodgetts, D., \& Chamberlain, K. (2006). Developing a critical media research agenda for health psychology. Journal of Health Psychology, 11(2), 317-327. https://doi.org/10.1177/ 1359105306061190 
Hurley, K., Breheny, M., \& Tuffin, K. (2017). Intergenerational inequity arguments and the implications for state-funded financial support of older people. Ageing and Society, 37(3), 561-580. https://doi.org/10.1017/S0144686X1500135X

Jaye, C., Lomax-Sawyers, I., Young, J., \& Egan, R. (2019). The people speak: Social media on euthanasia/assisted dying. Medical Humanities, (0), 1-9. https://doi.org/10.1136/medhum-2018011565

Keown, J. (1995). Euthanasia in the Netherlands: Sliding down the slippery slope. Notre Dame Journal of Law, Ethics \& Public Policy, 9(2), 407-448. https://doi.org/10.1525/sp.2007.54.1.23

Lewis, T. (2005). Euthanasia : A Foucauldian analysis [Masters Thesis]. Auckland University of Technologyhttp://hdl.handle.net/10292/143

Löfmark, R., Nilstun, T., Cartwright, C., Fischer, S., van der Heide, A., Mortier, F., Norup, M., Simonato, L., \& Onwuteaka-Philipsen, B. D. (2008). Physicians' experiences with end-of-life decision-making: Survey in 6 European countries and Australia. Biomed Central, 6(4), 1-8. https://doi. org/10.1186/1741-7015-6-4

Luna, F. (2009). Elucidating the concept of vulnerability : Layers not labels. International Journal of Feminist Approaches to Bioethics, 2(1), 121-139. https://doi.org/10.3138/ijfab.2.1.121

Lyons, A., \& Chamberlain, K. (2006). Health psychology: A critical introduction. Cambridge University Press.

Malpas, P. J., Anderson, A., Jacobs, P., Jacobs, T., Luinstra, D., Paul, D., Rauwhero, J., Wade, J., \& Wharemate, D. (2017). 'It's not all just about the dying'. Kaumātua Māori attitudes towards physician aid-in dying: A narrative enquiry. Palliative Medicine, 31(6), 544-552. https://doi.org/ $10.1177 / 0269216316669921$

Manch, T., \& Nyika, R. (2018). Palliative care specialists reject end of life choice bill. Stuff. https://stuff. co.nz

Mclnerney, F. (2007). Death and the body beautiful : Aesthetics and embodiment in press portrayals of requested death in Australia on the edge of the 21st century. Health Sociology Review, 16(5), 384-396. https://doi.org/10.5172/hesr.2007.16.5.384

Nichol, T. (2018). Terminally ill back euthanasia bill. The New Zealand Herald. https://www.nzherald. co.nz

O'Rourke, H. M., \& Ceci, C. (2013). Reexamining the boundaries of the "normal" in ageing. Nursing Inquiry, 20(1), 51-59. https://doi.org/10.1111/j.1440-1800.2011.00583.x

Oliver, M. (2013). The social model of disability: Thirty years on. Disability and Society, 28(7), 1024-1026. https://doi.org/10.1080/09687599.2013.818773

Ott, B., \& Mack, R. (2010). Critial media studies. John Wiley \& Sons.

Parker, I. (1998). Social constructionism: Discourse and realism. Sage Publications Inc.

Rankine, J., Moewaka-Barnes, A. M., Nairn, T., McManus, R., Anna-Lyse Abel, S., Borell, B., \& Gregory, A. (2014). Content and source analysis of newspaper items about Māori issues: Silencing the 'natives' in Aotearoa? Pacific Journalism Review, 20(1), 213-233. https://doi.org/10.24135/pjr. v20i1.195

Ranzijn, R. (2010). Active ageing-another way to oppress marginalized and disadvantaged elders?: Aboriginal elders as a case study. Journal of Health Psychology, 15(5), 716-723. https://doi.org/10. 1177/1359105310368181

Revell-Dennett, S. E. (2018). The right-to-die and the communal body [Doctoral Disseratation]. Victoria University of Wellington. https://doi.org/10.13140/RG.2.2.28739.25127

Ryan, A., Morgan, M., \& Lyons, A. (2011). The problem with death : Towards a genealogy of euthanasia. Paper presented at manawatu doctoral sesearch symposium 2011, Palmerston North, 43-48. http://mro.massey.ac.nz/handle/10179/2645

Saltes, N. (2013). "Abnormal" bodies on the borders of inclusion: Biopolitics and the paradox of disability surveillance. Surveillance and Society, 11(1-2), 55-73. https://doi.org/10.24908/ss.v11i1/ 2.4460

Schwartz, K. D., \& Lutfiyya, Z. M. (2009). "What lay ahead ... ": A media portrayal of disability and assisted suicide. Journal of Research in Special Educational Needs, 9(1), 27-38. https://doi.org/10. 1111/j.1471-3802.2009.01113.x

Seale, C. (1998). Constructing Death. Cambridge University Press. 
Seale, C. (2003). Health and media: An overview. Sociology of Health and IIIness, 25(6), 513-531. https://doi.org/10.1111/1467-9566.t01-1-00356

Shildrick, M. (2015). Death, debility and disability. Feminism \& Psychology, 25(1), 155-160. https://doi. org/10.1177/0959353514562816

Somerville, M. (2001). Death talk: The case against euthanasia and physician-assisted suicide (1st ed.). McGill-Queen's University Press.

Susan Austen trial verdict: not guilty of aiding suicide. (2018, February 23). Stuff. https://www.stuff. co.nz

Tuffin, K. (2005). Understanding critical social psychology. Sage Publications.

Turia, T. (2019 April 2). Euthanasia would undermine whānau values. The New Zealand Herald. https://www.nzherald.co.nz/

Türken, S., Nafstad, H., Blakar, R., \& Roen, K. (2015). Making sense of neoliberal subjectivity: A discourse analysis of media language on self-development. Globalizations, 13(1), 32-46. https://doi.org/10.1080/14747731.2015.1033247

Vulcănescu, S. G. (2018). The legal states of Euthanasia and its surrogates around the world. Apulia Theologica, 4(1), 195-209. https://trivent-publishing.eu/books/thebioethicsofthecrazyape/8.\% 20Sorin\%20Grigore\%20Vulcănescu.pdf

Wall, L. (2018). As on 9/11, choosing way you go is no sin. The New Zealand Herald. https://www. nzherald.co.nz

Walters, L. (2018). Last chance for say on voluntary euthanasia bill. Stuff. https://www.stuff.co.nz/

Willig, C. (2008). Discourse Analysis. In J. A. Smith (Ed.), Qualitative psychology. A practical guide to research methods (pp. 160-185). Sage Publications.

Winnington, R. (2016). Patient choice as illusion : Autonomy and choice in end-of-life care in the United Kingdom and New Zealand [Doctoral dissertation]. University of Auckland. http://hdl.handle.net/ 2292/31183

Woman accused of aiding suicide described dead woman as a 'contented customer', court told. (2018, February 14). Stuff. https://www.stuff.co.nz/

Yates, S., \& Hiles, D. (2010). Towards a "critical ontology of ourselves"?: Foucault, subjectivity and discourse analysis. Theory \& Psychology, 20(1), 52-75. https://doi.org/10.1177/0959354309345647

Young. (2018). National Party: ABC of National's contenders. The New Zealand Herald. https://www. nzherald.co.nz 